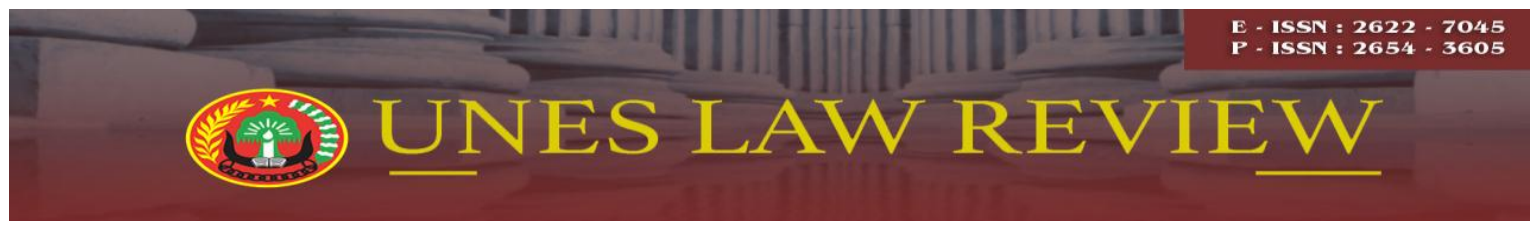

Email: uneslawreview@gmail.com

Online: http://review-unes.com/index.php/law

Volume 2, Issue 4, Juni 2020

\title{
KEBIJAKAN HUKUM DI TENGAH PENANGANAN WABAH CORONA VIRUS DISEASE (COVID-19)
}

\author{
${ }^{1}$ Julaiddin, ${ }^{2}$ Henny Puspita Sari \\ ${ }^{1}$ Fakultas Ilmu Hukum, Universitas Ekasakti, Padang Indonesia \\ Email: julaiddinmr@gmail.com \\ ${ }^{2}$ LPPM Universitas Ekasakti, Padang, Indonesia \\ Email: hennypuspitasari@unespadang.ac.id
}

\begin{abstract}
The handling of Covid-19 nationally is a unified action born of a comprehensive strategic policy. This policy should address the current state and anticipate its impact later. The efforts currently undertaken by the Government are: social distancing/physical distancing policy, protection for healthcare workers as the front guard, social restrictions on largescale, government transparency in the handling of Covid-19 pandemic, the validity of the test result data. For the treatment of this Covid-19 outbreak, law enforcement became one of the steps chosen by the government. The police officers are tasked with dissolving crowds, dealing with a liar or hoax, as well as a hoarders of staple material. In addition the police have also prepared a criminal threat for the violating community, the sanctions are in the information on the number of police in Mak/2/III/2020 regarding compliance with government policy in handling the spread of Corona Virus (Covid-19) and other forms of infringement or crime that may occur during PSBB in Kapolri Telegram mail number ST/1098/IV.
\end{abstract}

Kata Kunci: Kebijakan, Hukum, Penanganan, Wabah, Covid-19

\section{PENDAHULUAN}

Wabah virus Corona atau Covid-19 yang tengah melanda dunia saat ini, menjadi salah satu kekhawatiran masyarakat, meskipun pemerintah pada awalnya telah mengumumkan kasus infeksi Covid-19 secara resmi pada tanggal 2 Maret 2020, keberadaan virus ini lebih banyak tidak ditanggapi oleh masyarakat. Berbagai upaya yang telah dilakukan oleh pemerintah dalam bentuk himbauan belum benar-benar dipatuhi. Bahkan sebagian besar masyarakat menganggap bahwa virus tersebut tidak akan menyebar luas sebagaimana yang terjadi di Wuhan, China tempat awal penyebarannya virus tersebut.

Berbagai berita dan asumsi hoax yang berkembang mengenai kondisi cuaca dan iklim di Indonesia sebagai kondisi yang tidak akan menimbulkan penyebaran luas atau terkait ramuan/obat-obatan yang dianggap dapat mencegah timbulnya Covid-19 ternyata mampu 
mempengaruhi pola fikir masyarakat untuk tidak sepenuhnya menanggapi bahwa virus ini akan menjadi ancaman terbesar.

Saat ini Indonesia telah memasuki fase kritis dalam menghadapi pandemi Covid-19, ringkasan kasus pada tanggal 12 Mei 2020 di Indonesia telah terkonfirmasi positif sebanyak 14.749 jiwa, dengan data yang sembuh sebanyak 233 jiwa dan meninggal dunia sebanyak 3.063 jiwa (Kemenkes, 2020). Sedangkan di Sumatera Barat terdapat 319 jiwa yang telah terkonfirmasi positif, data pasien Covid-19 yang sembuh sebanyak 70 jiwa, dan meninggal dunia 18 jiwa. Kasus yang yang tertinggi di Sumatera Barat adalah kota Padang dengan jumlah kasus yang terkonfirmasi positif sebanyak 189 jiwa, yang sembuh sebanyak 43 jiwa dan meninggal dunia sebanyak 15 jiwa (Sumbar Provinsi, 2020).

Sehingga berjalannya waktu keberadaan virus ini mulai meresahkan terutama ketika pemerintah menetapkan mengenai protokol pemakaman bagi penderita Covid 19 yang oleh masyarakat dianggap sangat menakutkan, karena pasien yang meninggal dunia akibat Covid-19 tidak dapat diperlakukan sebagaimana mestinya oleh keluarga. Selain itu, karantina terhadap warga yang melakukan perjalanan ke daerah terinfeksi menjadi salah satu kekhawatiran masyarakat, sehingga masyarakat tidak lagi berfikir bahwa virus ini merupakan wabah yang dianggap enteng. Semenjak meningkatnya kasus terkonfirmasi Covid-19 di setiap daerah, sehingga menimbulkan kekhawatiran dan keresahan masyarakat terhadap meluasnya penyebaran virus tersebut.

Untuk menjaga agar penyebaran wabah Covid-19 tidak semakin meluas, pemerintah pusat dan pemerintah daerah di masing-masing provinsi dan kabupaten/kota telah mengambil langkah antisipasi atau kesiapsiagaan agar wabah tidak menelan korban yang lebih besar. Kesiapsiagaan tersebut terlihat dari kebijakan-kebijakan yang telah di keluarkan oleh pemerintah pusat dan diturunkan kepemerintah daerah. Langkah demikian harus dibangun secara baik dan sinergis oleh pemerintah, salah satunya yang menjadi garda terdepan yang dipilih oleh pemerintah adalah para penegakan hukum.

Aparat kepolisian menjadi garda terdepan dalam mengatasi wabah virus corona di Tanah Air. Secara garis besar, polisi bertugas dalam membubarkan kerumunan massa, menangani penyebar berita bohong atau hoax, serta penimbun bahan pokok. Untuk itu, Kapolri Jenderal (Pol) Idham Azis telah memberikan sejumlah arahan kepada jajarannya dalam penanganan wabah Covid-19. Polisi juga menyiapkan ancaman pidana bagi mereka 
yang melanggar yang dituang dalam Maklumat Kapolri Nomor Mak/2/III/2020 tentang Kepatuhan terhadap Kebijakan Pemerintah dalam Penanganan Penyebaran Virus Corona (Covid-19) yang ditandatangani oleh Jenderal Polisi Drs. Idham Azis pada tanggal 19 Maret 2020.

\section{METODE PENELITIAN}

Metode yang digunakan dalam penelitian ini adalah analisis isi atau content analysis, yang menggunakan data sekunder yaitu penelitian yang bersifat pembahasan mendalam terhadap isi suatu dokumen tertulis baik dari buku maupun tulisan ilmiah lainnya yang relevan dengan kebijakan hukum di tengah penanganan wabah Corona Virus Disease (Covid-19)

\section{HASIL PENELITIAN DAN PEMBAHASAN}

\section{Sinergi Tiga Kebijakan Penanganan Covid-19}

Penanganan Covid-19 secara nasional merupakan kesatuan tindakan yang lahir dari kebijakan strategis komprehensif. Kebijakan ini harus mengatasi kondisi terkini dan mengantisipasi dampaknya di kemudian. Keselamatan dan keamanan masyarakat harus terjamin dan tidak sekadar menjadi materi perdebatan.

Tiga kebijakan perlu disinergikan agar penanganan Covid-19 dapat menjamin kelangsungan hidup (Media Indonesia, 2020), yaitu:

1. Kebijakan yang menguatkan ketersediaan dan keandalan infrastruktur penanganan Covid-19.

Sejauh ini, upaya pemerintah serta profesionalitas garda depan kesehatan dapat disebut sebagai fondasi penanganan Covid-19. Meskipun belum mampu menghentikan persebaran virus, kesigapan pemerintah dan tenaga medis terbukti mampu menghambat dan melokalisasi persebaran. Fondasi penanganan Covid-19 perlu diperluas dan diperkuat. Kesigapan, profesionalitas, dan kerelawanan tim kesehatan harus diimbangi jaminan kesehatan dan keselamatan yang sama. Upaya meminimalkan risiko perlu disertai ketercukupan alat pelindung diri (APD) berkualitas serta peralatan medis mumpuni. Ketersediaan rumah sakit dan kapasitas penanganannya juga harus mampu menangani ledakan pasien di daerah.

2. Kebijakan untuk penyelenggaraan edukasi bahaya Covid-19 bagi seluruh masyarakat, utamanya masyarakat kelas menengah ke bawah.

Dengan asumsi masyarakat menengah ke atas mampu mengamankan dirinya, edukasi sosial sangat diperlukan masyarakat menengah ke bawah. Kompleksitas edukasi sosial ini akan cenderung menebal karena persoalan kehidupan masyarakat di Indonesia bersifat khas. Meskipun hal ini terlihat mudah, dalam kenyataannya tidaklah 
sederhana. Sejauh tidak ada kebijakan edukasi sosial yang tepat, keresahan dan kepanikan masyarakat menengah ke bawah akan tetap berlangsung. Informasi tak terkendali tentang Covid-19 dan kegagalan persuasi memutus rantai persebaran, menjadi cermin tidak adanya perubahan sikap dan perilaku. Bila hal ini berlanjut, dampak fungsional juga tidak akan berjalan untuk edukasi bahaya Covid-19. Selain itu, sifat komunal dan pola mata pencarian kerap menegasi langkah terapan edukasi sosial. Kebijakan edukasi sosial bahaya Covid-19 harus disusun secara sistematis tanpa menimbulkan keresahan dan kepanikan masyarakat.

3. Kebijakan nasional untuk memobilisasi dunia industri berpartisipasi menghadapi Covid-19.

Pelibatan industri nasional dilakukan dengan meminta mereka untuk sementara waktu memproduksi secara massal peralatan pencegahan, pemeriksaan, dan penanganan Covid-19. Usaha yang demikian diarahkan untuk mencukupi ketersediaan masker, sanitizer, APD, serta bahan pangan bagi kalangan yang rentan pada kebutuhan primer ini.

\section{Aspek Hukum Penanganan Penyebaran Covid-19}

Kesehatan dipandang tidak lagi sekedar urusan pribadi yang terkait dengan nasib atau karunia Tuhan yang tidak ada hubungannya dengan tanggung jawab negara, melainkan suatu hak hukum (legal rights) yang tentunya dijamin oleh negara secara konstitusional (Majda El-Muthtaj, 2009). Untuk mewujudkan derajat kesehatan yang optimal bagi setiap orang, yang merupakan bagian dari kesejahteraan, diperlukan dukungan hukum. Hak atas derajat kesehatan yang optimal akan semakin kuat klaimnya jika dijustifikasi dengan jalan mengaitkannya dengan hak hidup, berhak atas hidup ekivalen dengan berhak atas derajat kesehatan yang optimal (Titon Slamet Kurnia, 2007).

Konstitusi Republik Serikat (RIS) 194 telah mengatur jaminan konstitusi terhadap hak atas kesehatan yaitu: Penguasa senantiasa berusaha dengan sunguh-sungguh memajukan kebersihan umum dan kesehatan rakyat. Ketentuan Pasal 40 Konstitusi RIS di adopsi ke dalam Pasal 42 UUDS. Sejalan dengan itu, Konstitusi World Health Organization (WHO) 1948 telah menegaskan pula bahwa: memperoleh derajat kesehatan yang setinggi-tingginya adalah suatu hak asasi bagi setiap orang (the enjoyment of the highest attainable standard of health is one of the fundamental rights of every human being) ( Eleanor D. Kinney, 2006).

Didalam perubahan kedua Undang-Undang Dasar 1945, ditegaskan bahwa kesehatan sebagai bagian dari hak asasi manusia. Dalam Pasal 28H ayat (1) dinyatakan, bahwa: "Setiap orang berhak hidup sejahtera lahir dan batin, bertempat tinggal, dan 
mendapat lingkungan hidup yang baik dan sehat serta berhak memperoleh pelayanan kesehatan", hal ini menggambarkan adanya perubahan paradigma yang luar biasa, dilihat dari regulasi yang dikeluarkan oleh pemerintah tentang upaya perlindungan dan pencegahan penyakit menular (Manado Post, 2020) yaitu:

1. Pasal 4 ayat (1) Undang-Undang Dasar Negara Republik Indonesia Tahun 1945;

2. Undang-Undang Nomor 4 Tahun 1984 tentang Wabah Penyakit Menular (Lembaran Negara Republik Indonesia Tahun 1984 Nomor 20, Tambahan Lembaran Negara Republik Indonesia Nomor 3273);

3. Undang-Undang Nomor 24 Tahun 2007 tentang Penanggulangan Bencana (Lembaran Negara Republik Indonesia Tahun 2007 Nomor 66, Tambahan Lembaran Negara Republik Indonesia Nomor 4723);

4. Undang-Undang Nomor 36 Tahun 2009 tentang Keschatan (Lembaran Negara Republik Indonesia Tahun 2009 Nomor 144, Tambahan Lembaran Negara Republik Indonesia Nomor 5063);

5. Undang-Undang Nomor 6 Tahun 2018 tentang Kekarantinaan Kesehatan (Lembaran Negara Republik Indonesia Tahun 2018 Nomor 128, Tambahan Lembaran Negara Republik Indonesia Nomor 6236);

6. Peraturan Presiden Nomor 17 Tahun 2018 tentang Penyelenggaraan Kedaruratan Bencana pada Kondisi Tertentu (Lembaran Negara Republik Indonesia Tahun 2018 Nomor 34).

Berpedoman pada aturan-aturan di atas, kemudian dalam upaya penanggulangan wabah Covid-19, pemerintah telah menerbitkan beberapa regulasi yaitu :

1. Instruksi Presiden Nomor 4 Tahun 2020 tentang refocussing kegiatan, realokasi anggaran serta pengadaan barang dan jasa dalam rangka percepatan penanganan Covid-19;

2. Keputusan Presiden Nomor 11 tahun 2020 tentang Penetapan Kedaruratan Kesehatan Masyarakat Covid-19;

3. Keputusan Presiden Nomor 12 Tahun 2020 tentang penetapan bencana non alam penyebaran Covid-19 sebagai Bencana Nasional;

4. Peraturan Pemerintah No. 21 tahun 2020 tentang Pembatasan Sosial Berskala Besar dalam rangka Percepatan Penanganan Covid-19 ditetapkan di Jakarta pada tanggal 31 Maret 2020 oleh Presiden Joko Widodo;

5. Keputusan Presiden Nomor 7 Tahun 2020 Tentang Gugus Tugas Percepatan Penanganan Covid-19;

6. Keputusan Presiden Nomor 9 Tahun 2020 tentang Perubahan Atas Keputusan Presiden Nomor 7 Tahun 2020 Tentang Gugus Tugas Percepatan Penanganan Covid-19.

\section{Upaya Pemerintah Di Tengah Penanganan Wabah Covid-19}

Penerbitan regulasi dalam rangka penanganan penyebaran Covid-19 merupakan upaya untuk mendukung keberadaan Undang-Undang Nomor 24 Tahun 2007 yang 
menetapkan wabah penyakit sebagai salah satu bencana non-alam yang perlu dikelola potensi ancamannya. Atas regulasi-regulasi tersebut maka upaya-upaya yang saat ini dilakukan oleh pemerintah adalah :

\section{Kebijakan Social Distancing/Physical Distancing}

Adanya Social Distancing sejauh ini sangat efektif dalam menghambat penyebaran virus/penyakit, yakni dengan mencegah orang sakit melakukan kontak dekat dengan orang-orang untuk mencegah penularan. Namun melihat fenomena sekarang, nyatanya social distancing masih berbentuk imbauan yang jika tidak dibantu diviralkan di media sosial akan lebih sedikit mayarakat yang mengetahuinya. Maka dari itu, sebaiknya kebijakan social distancing harus dimuat dalam peraturan pemerintah pengganti undang-undang tentang upaya penanganan wabah Covid-19, yang salah satunya mengatur social distancing adalah kewajiban, jika perlu terdapat penegasan berupa sanksi sesuai hukum positif, agar masyarakat tidak hanya sadar akan pentingnya social distancing tetapi juga menerapkan praktiknya. Hal ini dirasa perlu untuk melakukan pembatasan hak individual dalam melakukan social distancing karena kondisi yang terjadi adalah kegentingan yang mengancam kesehatan publik.

Istilah social distancing kemudian mengalami perubahan menjadi physical distancing sesuai dengan istilah yang digunakan WHO karena penggunaan istilah social distancing seolah-olah melakukan penghentian interaksi sosial dalam masyarakat sementara yang sebenarnya diinginkan hanya menjaga jarak fisik. Dari hal inilah kemudian berbagai aktivitas yang pada awalnya dilakukan dengan jarak fisik yang dekat kemudian diubah menjadi aktivitas yang menciptakan jarak secara fisik antara lain, pembelajaran online (metode daring), penggunaan mekanisme WFH (work from home), penutupan tempat-tempat perbelanjaan ( $m a l l$ ) dan upaya lain yang dapat mencegah penyebaran Covid 19.

2. Perlindungan bagi Tenaga Kesehatan sebagai Garda Depan

Tenaga kesehatan berdiri di garda depan dalam mencegah bertambahnya jumlah infeksi sehingga pemerintah perlu menjamin perlindungan dan keselamatan kerja bagi tenaga medis dalam upaya penanganan Covid-19. Perlindungan tenaga kesehatan bergulir setelah ada tujuh dokter meninggal karena positif terinfeksi, kelelahan hingga serangan jantung sehingga dilakukan pengaturan jam kerja, penambahan jumlah rumah 
sakit rujukan, pemenuhan kebutuhan primer setiap tenaga kesehatan, penyediaan Alat Pelindung Diri (APD), kemudian penentuan skala prioritas pemberian APD.

Kepastian hukum merupakan instrumen penting dalam menjamin keselamatan tenaga kesehatan sehingga pemerintah tidak dapat melakukan tindakan sewenangwenang terhadap penugasan tenaga kesehatan. Terlebih jika melihat peraturan perundang-undangan mengenai tenaga kesehatan nampaknya belum ada yang mengatur penjaminan kepastian hukum bagi tenaga kesehatan sekalipun sudah ada Undangundang Nomor 36 Tahun 2014 tentang Tenaga Kesehatan namun saat ini belum ada peraturan pelaksanaan dan petunjuk teknis Undang-undang Tenaga kesehatan dan undang-undang lainnya yang mengatur tentang perlindungan hukum dan keselamatan kerja bagi Tenaga kesehatan.

3. Pembatasan Sosial Berskala Besar

Kewenangan Pembatasan Sosial Bersklala besar berdasarkan Undang-Undang Nomor 6 Tahun 2018 tentang Kekarantinaan Kesehatan merupakan wewenang absolut Pemerintah Pusat. Dalam Pasal 1 Angka 1 dinyatakan bahwa "kekarantinaan kesehatan dilakukan untuk mencegah dan menangkal keluar atau masuknya penyakit dan/atau faktor risiko kesehatan masyrakat yang berpotensi menimbulkan kedaruratan kesehatan masyarakat". Maka dari itu jika ada pemerintah daerah yang merasa daerahnya memiliki situasi kedaruratan dan hendak melakukan lockdown, tentunya hal ini inkonstitusional dan perlu adanya konsul dari kepala daerah dengan pemerintah pusat sebelum mengambil kebijakan terkait. Kemudian atas kondisi darurat penyebaran Covid 19, pemerintah kemudian menetapkan Peraturan Pemerintah No. 21 Tahun 2020 tentang Pembatasan Sosial Berskala Besar dalam rangka Percepatan Penanganan Covid-19.

Pertimbangan PP 21 tahun 2020 tentang Pembatasan Sosial Berskala Besar dalam rangka Percepatan Penanganan Covid-19 adalah:

a. bahwa penyebaran Covid-19 dengan jumlah kasus dan/atau jumlah kematian telah meningkat dan meluas lintas wilayah dan lintas negara dan berdampak pada aspek politik, ekonomi, sosial, budaya, pertahanan dan keamanan, serta kesejahteraan masyarakat di Indonesia;

b. bahwa dampak penyebaran Covid-19 telah mengakibatkan terjadi keadaan tertentu sehingga perlu dilakukan upaya penanggulangan, salah satunya dengan tindakan pembatasan sosial berskala besar; 
Peraturan Pemerintah No. 21 tahun 2020 tentang Pembatasan Sosial Berskala Besar dalam rangka Percepatan Penanganan Covid-19 mengatur tentang Pelaksanaan Pembatasan Sosial Berskala Besar yang ditetapkan oleh Menteri Kesehatan dan dapat dilakukan oleh Pemerintah Daerah berdasarkan persetujuan Menteri Kesehatan. PP 21 tahun 2020 tentang Pembatasan Sosial Berskala Besar dalam rangka Percepatan Penanganan Covid-19 tentunya diputuskan dengan pertimbangan yang banyak sesuai kultur negara Indonesia. Kebijakan lockdown tidak menjadi pilihan pemerintah sebagaimana diterapkan dibanyak negara, India misalnya menyebabkan chaos dan permasalahan sosial yang mengagetkan. Namun kunci dari hal ini pembatasan diri dan pergerakan individu warga negara untuk tinggal di rumah, membatasi frekuensi dan jumlah pertemuan massal untuk kemudian dapat menaklukan coronavirus pandemi ini.

4. Transparansi pemerintah dalam penanganan pandemi Covid-19.

Keterbukaan informasi mengenai Covid 19 menjadi sebuah kemestian saat ini. Keterbukaan informasi mengenai Covid 19 pada dasarnya mengacu pada UU No.14 Tahun 2008 tentang informasi publik menuntut. Pemerintah sebagai badan publik untuk membuka secara transparan kasus ini sejak awal. Pada awalnya, informasi mengenai pasien dan data infeksi virus ini tidak terbuka bahkan nama pasien pun dirahasiakan.

Alasan pemerintan tidak membuka seluruh informasi terkait penanganan virus korona yang disebabkan karena kekhawatiran menimbulkan kepanikan dan keresahan namun kemudian seiring perkembangan kondisi penyebaran virus ini maka keterbukaan data pun mulai dilakukan karena pemerintah perlu menyampaikan kepada masyarakat data-data pasien yang meninggal atau positif untuk dapat mengetahui rantai penyebaran virus tersebut.

Mengacu pada UU No. 14 tahun 2008, pandemi COVID-19 bukan informasi publik yang dikecualikan oleh Undang-Undang, sebagaimana informasi yang dapat membahayakan negara, karena sejatinya informasi pandemi tersebut sudah diketahui khalayak umum sejak hari pertama mewabah di Wuhan, Tiongkok, dan telah diinformasikan oleh badan kesehatan dunia, WHO. Selanjutnya terdapat ketentuanketentuan yang mewajibkan Pemerintah dan Pemerintah Daerah di luar UU No.14 Tahun 2008 untuk memberikan informasi sejelas-jelasnya dan membuka akses bagi 
masyarakat untuk mengetahui informasi tentang kesehatan ataupun penyakit menular, yakni Pasal 17, Pasal 154 dan 155 UU No.36 tahun 2009. Di samping itu juga, pasal 79 dan 80 UU No.6 Tahun 2018 tentang Kekarantinaan Kesehatan memberikan landasan otoritas bagi pemerintah pusat dan daerah untuk menyampaikan informasi kekarantinaan kesehatan sebagai bagian dari pencegahan dan pemberantasan risiko kesehatan masyarakat yang dapat menyebabkan kedaruratan.

5. Validitas Data Hasil Pemeriksaan

Pemeriksaan kesehatan terkait dengan Covid 19 dilakukan dengan 2 (dua) cara yaitu rapid test dan swap test dan dari kedua cara ini maka cara kedua merupakan cara yang dianggap paling valid. Tetapi realitas yang kemudian muncul adalah hasil pemeriksaan metode swap test ternyata banyak pula yang menimbulkan masalah karena waktu penentuan hasil pemeriksaan memakan waktu agak lama sehingga beberapa pasien yang meninggal dalam status ODP kemudian setelah dilakukan pemakaman dengan protokol Covid ternyata setelah adanya hasil pemeriksaan, justru negatif. Keterbatasan dalam pemeriksaan metode swap test saat ini menjadi kendala yang besar dalam penanganan Covid 19.

Berdasarkan kondisi-kondisi di atas maka dapat dikatakan bahwa ditinjau dari aspek hukum, berbagai regulasi telah diterbitkan untuk mencegah penyebaran Covid 19 namun realitas sampai saat ini menunjukkan bahwa belum ada perubahan signifikan dalam penanganan kasus Covid 19 di Indonesia, jumlah pasien semakin bertambah, angka kematian pun semakin melaju. Keberadaan regulasi yang ada tidak akan efektif apabila tidak didukung dengan upaya yang lebih tegas namun santun di dalam masyarakat. Eksistensi dan atensi ekstra dari seluruh pihak terkait menjadi sangat urgen untuk memberikan pemahaman kepada masyarakat mengenai penyebaran virus ini.

Kepolisian, aparat pemerintah daerah dari level tertinggi sampai level terendah, aparat TNI, Lembaga-lembaga negara perlu untuk melakukan sosialisasi dan pendekatan kepada masyarakat untuk memberikan pemahaman mengenai pentingnya untuk melakukan tindakan yang preventif terhadap penyebaran virus ini. Pemerintah harus mampu memberikan jawaban atas kekhawatiran masyarakat dengan adanya pembatasan sosial baik skala kecil maupun skala besar. 


\section{Penerapan Penegakan Hukum di Tengah Penanganan Wabah Covid-19}

Untuk penanganan wabah Covid-19 ini, penegakan hukum menjadi salah satu langkah yang dipilih oleh pemerintah. Aparat kepolisian bertugas dalam membubarkan kerumunan massa, menangani penyebar berita bohong atau hoax, serta penimbun bahan pokok. Selain itu pihak kepolisian juga telah mempersiapkan ancaman pidana bagi masyarakat yang melanggar, sanksi tersebut terdapat dalam Maklumat Kapolri Nomor Mak/2/III/2020 tentang Kepatuhan terhadap Kebijakan Pemerintah dalam Penanganan Penyebaran Virus Corona (Covid-19).

Dalam maklumat tersebut tertulis bahwa masyarakat tidak berkerumun. Tidak mengadakan kegiatan sosial kemasyarakatan yang menyebabkan berkumpulnya massa dalam jumlah banyak, baik di tempat umum maupun di lingkungan itu sendiri. Adapun, tindakan pengumpulan massa terdiri atas lima hal, yaitu:

1. pertemuan sosial, budaya, keagamaan dan aliran kepercayaan dalam bentuk seminar, lokakarya, sarasehan dan kegiatan lainnya yang sejenis.

2. kegiatan konser musik, pekan raya, festival, bazar, pasar malam, pameran dan resepsi keluarga.

3. kegiatan olahraga, kesenian, dan jasa hiburan.

4. unjuk rasa, pawai dan karnaval, dan

5. kegiatan lain yang menjadikan berkumpulnya massa.

Bagi masyarakat yang masih membandel dan tidak mengindahkan perintah personel yang bertugas untuk kepentingan masyarakat, bangsa dan negara, maka akan diproses secara hukum dengan ancaman pidana yang telah di atur dalam Maklumat Kapolri Nomor Mak/2/III/2020 tentang Kepatuhan terhadap Kebijakan Pemerintah dalam Penanganan Penyebaran Virus Corona (Covid-19), yaitu Pasal 212 KUHP, Pasal 216 KUHP, dan Pasal 218 KUHP ancaman hukumannya adalah satu tahun empat bulan penjara.

Upaya lain yang dilakukan oleh pemerintah adalah dengan penerapan Pembatasan Sosial Berskala Besar (PSBB) dalam rangka penyebaran virus corona. Adanya upaya yang dilakukan oleh pemerintah sehingga Kapolri mengambil langkah-langkah penegak hukum dalam menganggapi PSBB tersebut, dengan mengeluarkan Surat Telegram Kapolri Nomor ST/1098/IV/HUK.7.1./2020, yang ditandatangani oleh Kepala Badan Reserse Kriminal (Kabareskrim) Polri Komjen Listyo Sigit Prabowo. 
Dalam Surat Telegram Kapolri tersebut dijelaskan bahwa ancaman pidana bagi masyarakat yang melawan imbauan polisi dalam penanganan Covid-19 dalam hal menolak atau melawan petugas yang berwenang sebagaimana Pasal 212 sampai dengan Pasal 218 KUHP dan menghalangi pelaksanaan penanggulangan wabah penyakit di tambah, bentuk regulasinya, (Kompas Nasional, 2020) yaitu:

a. Undang-Undang Nomor 4 Tahun 1984 tentang Wabah Penyakit Menular Pasal 14 ayat (1) dan (2), yaitu:

(1) Barang siapa dengan sengaja menghalangi pelaksanaan penanggulangan wabah sebagaimana diatur dalam Undang-Undang ini, diancam dengan pidana penjara selama-lamanya 1 (satu) tahun dan/atau denda setinggitingginya Rp 1.000.000,- (satu juta rupiah).

(2) Barang siapa karena kealpaannya mengakibatkan terhalangnya pelaksanaan penanggulangan wabah sebagaimana diatur dalam Undang-Undang ini, diancam dengan pidana kurungan selama-lamanya 6 (enam) bulan dan/atau denda setinggi-tingginya $\mathrm{Rp}$ 500.000,- (lima ratus ribu rupiah).

b. Selain itu pihak kepolisi juga mengantisipasi bentuk pelanggaran atau kejahatan yang mungkin terjadi selama PSBB yaitu: kejahatan yang terjadi pada saat arus mudik (street crime), kerusuhan/penjarahan yaitu pencurian dengan kekerasan, pencurian dengan pmberatan. Tindak pidana tersebut sebagaimana dimaksud dalam Pasal 362, 363, 365, 406, dan 170 KUHP.

c. Upaya menghambat kemudahan akses sebagaimana diatur dalam Undang-Undang Nomor 24 Tahun 2007 tentang Penanggulangan Bencana Pasal 77 juncto Pasal 50 Ayat (1) dan Pasal 79 Ayat (1) dan (2).

d. Masyarakat yang tidak mematuhi atau melanggar penyelenggaraan kesehatan seperti tertuang Pasal 93 Undang-Undang Nomor 6 Tahun 2018 tentang Kekarantinaan Kesehatan.

e. Memainkan harga atau menimbun bahan pokok disangkakan Pasal 29 dan Pasal 107 Undang-Undang Nomor 7 Tahun 2014 tentang Perdagangan, dan Pasal 62 Undang-Undang Nomor 8 Tahun 1999 tentang Perlindungan Konsumen, serta UU lain yang terkait.

f. Oknum yang menghambat jalur distribusi pangan dikenakan Pasal 107 huruf $\mathrm{f}$ Undang-Undang Nomor 27 Tahun 1999 tentang Perubahan KUHP yang berkaitan dengan Kejahatan terhadap Keamanan Negara.

g. Penghina Presiden dan Pejabat

Bentuk pelanggaran atau kejahatan yang mungkin saja terjadi berupa penghinaan kepada penguasa/Presiden dan pejabat pemerintah sebagaimana dimaksud Pasal 207 KUHP. Sesuai Pasal 207 KUHP, maka penghinaan itu bisa terancam pidana penjara paling lama 1 tahun 6 bulan.

h. Ketahanan akses data internet selama masa darurat

Penyebaran hoax terkait Covid-19 dan kebijakan pemerintahan dalam mengantisipasi penyebaran wabah Covid-19 sebagaimana dimaksud dalam Pasal 14 atau Pasal 15 Undang-Undang Nomor 1 Tahun 1946 tentang Peraturan Hukum Pidana. 
i. Praktik penipuan penjualan onlinealat-alat kesehatan, masker, alat pelindung diri (APD), antiseptik, obat-obatan dan disinfektan sebagaimana dimaksud Pasal 45A ayat (1) juncto Pasal 28 ayat (1) UU ITE.

j. Serta kejahatan orang yang tidak mematuhi penyelenggaraan karantina kesehatan dan atau menghalangi sebagaimana Undang-Undang Nomor 6 Tahun 2018 tentang Kekarantinaan Kesehatan Pasal 93.

\section{PENUTUP}

Penanganan Covid-19 secara nasional merupakan kesatuan tindakan yang lahir dari kebijakan strategis komprehensif. Kebijakan ini harus mengatasi kondisi terkini dan mengantisipasi dampaknya di kemudian. Kesehatan dipandang tidak lagi sekedar urusan pribadi yang terkait dengan nasib atau karunia Tuhan yang tidak ada hubungannya dengan tanggung jawab negara, melainkan suatu hak hukum (legal rights) yang tentunya dijamin oleh negara secara konstitusional didalam Konstitusi Republik Serikat (RIS) 194 dan ditegasakan dalam Undang-Undang Dasar 1945 Pasal 28H ayat (1).

Berpedoman pada aturan-aturan tersebut, dalam upaya penanggulangan wabah Covid-19, pemerintah telah menerbitkan beberapa regulasi. Penerbitan regulasi dalam rangka penanganan penyebaran Covid-19 merupakan upaya untuk mendukung keberadaan Undang-Undang Nomor 24 Tahun 2007 yang menetapkan wabah penyakit sebagai salah satu bencana non-alam yang perlu dikelola potensi ancamannya. Upaya-upaya yang saat ini dilakukan oleh pemerintah adalah: kebijakan social distancing/physical distancing, perlindungan bagi tenaga kesehatan sebagai garda depan, pembatasan sosial berskala besar, transparansi pemerintah dalam penanganan pandemi Covid-19, validitas data hasil pemeriksaan.

Untuk penanganan wabah Covid-19 ini, penegakan hukum menjadi salah satu langkah yang dipilih oleh pemerintah. Aparat kepolisian bertugas dalam membubarkan kerumunan massa, menangani penyebar berita bohong atau hoax, serta penimbun bahan pokok. Selain itu pihak kepolisian juga telah mempersiapkan ancaman pidana bagi masyarakat yang melanggar, sanksi tersebut terdapat dalam Maklumat Kapolri Nomor Mak/2/III/2020 tentang Kepatuhan terhadap Kebijakan Pemerintah dalam Penanganan Penyebaran Virus Corona (Covid-19) dan bentuk pelanggaran atau kejahatan yang mungkin terjadi selama PSBB dalam Surat Telegram Kapolri Nomor ST/1098/IV/HUK.7.1./2020. 


\section{DAFTAR PUSTAKA}

\section{Buku Teks:}

Majda El-Muthtaj, 2009, Hak Asasi Manusia dalam Konstitusi Indonesia, Cek. 3, Kencana renada Media Group, Jakarta.

Titon Slamet Kurnia, 2007, Derajat Kesehatan Optimal sebagai HAM di Indonesia, PT. Alumni, Bandung.

\section{Jurnal \& Internet :}

Eleanor D. Kinney. 2006. "The International Human Right to Health", Indiana Law Review, Vol 34, page 1559.

https://covid19.kemkes.go.id

https://corona.sumbarprov.go.id.

https://mediaindonesia.com/read/2020/03/24/298499-kebijakan-antisipatif-inovatifpenanganan-covid-19

http://manadopost.id/read/2020/04/20/Aspek-Hukum-Dalam-Dalam-Penanganan-WabahCovid-19/67536

https://nasional.kompas.com/read/2020/04/06/10272001/langkah-hukum-di-tengahpenanganan-wabah-covid-19-ini-pelanggaran-yang?page $=3$

\section{Peraturan Undang-Undang :}

Undang-Undang Dasar Negara Republik Indonesia Tahun 1945.

Undang-Undang Nomor 4 Tahun 1984 tentang Wabah Penyakit Menular (Lembaran Negara Republik Indonesia Tahun 1984 Nomor 20, Tambahan Lembaran Negara Republik Indonesia Nomor 3273).

Undang-Undang Nomor 24 Tahun 2007 tentang Penanggulangan Bencana (Lembaran Negara Republik Indonesia Tahun 2007 Nomor 66, Tambahan Lembaran Negara Republik Indonesia Nomor 4723).

Undang-Undang Nomor 36 Tahun 2009 tentang Keschatan (Lembaran Negara Republik Indonesia Tahun 2009 Nomor 144, Tambahan Lembaran Negara Republik Indonesia Nomor 5063).

Undang-Undang Nomor 6 Tahun 2018 tentang Kekarantinaan Kesehatan (Lembaran Negara Republik Indonesia Tahun 2018 Nomor 128, Tambahan Lembaran Negara Republik Indonesia Nomor 6236).

Peraturan Presiden Nomor 17 Tahun 2018 tentang Penyelenggaraan Kedaruratan Bencana pada Kondisi Tertentu (Lembaran Negara Republik Indonesia Tahun 2018 Nomor 34).

Instruksi Presiden Nomor 4 Tahun 2020 tentang refocussing kegiatan, realokasi anggaran serta pengadaan barang dan jasa dalam rangka percepatan penanganan Covid-19. 
Keputusan Presiden Nomor 11 tahun 2020 tentang Penetapan Kedaruratan Kesehatan Masyarakat Covid-19.

Keputusan Presiden Nomor 12 Tahun 2020 tentang penetapan bencana non alam penyebaran Covid-19 sebagai Bencana Nasional.

Peraturan Pemerintah No. 21 tahun 2020 tentang Pembatasan Sosial Berskala Besar dalam rangka Percepatan Penanganan Covid-19 ditetapkan di Jakarta pada tanggal 31 Maret 2020 oleh Presiden Joko Widodo.

Keputusan Presiden Nomor 7 Tahun 2020 Tentang Gugus Tugas Percepatan Penanganan Covid-19.

Keputusan Presiden Nomor 9 Tahun 2020 tentang Perubahan Atas Keputusan Presiden Nomor 7 Tahun 2020 Tentang Gugus Tugas Percepatan Penanganan Covid-19. 